\title{
In Vitro Sensitivity Research Concerning Some Microorganisms at Hydroxyquinoline and Cupric Derivatives Deposited onto Hydroxyapatite
}

\author{
Sorin RĂPUNTEAN ${ }^{1 *}$, Alexandru POP², Vasile MICLĂUȘ ${ }^{2}$, Corina GARBO ${ }^{2}$, \\ Flore CHIRILA $\breve{ }^{1}$, Gheorghe RĂPUNTEAN ${ }^{1}$, Nicodim FIȚ ${ }^{1}$, Horea FARCĂU ${ }^{1}$, Maria TOMOAIA-COTISEL ${ }^{2}$ \\ ${ }^{1}$ University of Agricultural Sciences and Veterinary Medicine Cluj-Napoca, Faculty of Veterinary \\ Medicine, 3-5 Mănăştur Street, 400372, Romania \\ ${ }^{2}$ Babeș-Bolyai University (UBB), Faculty of Chemistry and Chemical Engineering, Cluj-Napoca, 11 Arany \\ Janos Street, 400028, Romania \\ *corresponding author: sorin.rapuntean@gmail.com
}

Bulletin UASVM Veterinary Medicine 73(2) / 2016,

Print ISSN 1843-5270; Electronic ISSN 1843-5378

DOI:10.15835/buasvmcn-vm: 12203

\begin{abstract}
The preparations based on hydroxyquinoline, in various combinations, are used in medicine, being shown to have an inhibitory effect against bacteria, molds, fungi, parasites, and viruses, but also having other beneficial effects mentioned in other medical conditions (anti-cancer, anti-degenerative, anti-inflammatory).

In vitro susceptibility testing of microorganisms: bacteria (Gram positive and Gram negative), yeast (Candida spp.,) and unicellular algae (Prototheca spp.) at the preparations based on hydroxyquinoline (HQ) and its cupric derivatives deposited on hydroxyapatite (HAP).

There were tested microbial strains of the following genera: Escherichia, Staphylococcus, Micrococcus, Bacillus, Candida, and Prototheca. The tested products (developed in the Laboratory for Nanobiomaterials Synthesis, Center of Physical Chemistry, Faculty of Chemistry and Chemical Engineering, UBB Cluj-Napoca) were developed in three versions: 1) $\mathrm{HQ}-\mathrm{Cu}^{2+}-\mathrm{HAP}_{1}$; 2) $\mathrm{HQ}-\mathrm{Cu}^{2+}-\mathrm{HAP}_{2}$; and 3) $\mathrm{NHQ}-\mathrm{Cu}^{2+}-\mathrm{HAP}_{2}$, where NHQ stands for nitro hydroxyquinoline. Determination of the inhibitory effect was conducted by diffusion technique in Mueller-Hinton agar (MHA), according to CLSI 2013 standards, with necessary adaptations for testing of products made in the form of suspensions. Following interpretation, it was found that the inhibition zones, arising from the antimicrobial effect of the tested products showed variability in size, depending on the test product and the microbial strain: Escherichia coli (8-10 mm), Staphylococcus sp. (17.6 - $23.2 \mathrm{~mm})$, Micrococcus spp. (24.4 - $27.6 \mathrm{~mm})$, Bacillus spp. (14.0 - $16.0 \mathrm{~mm})$, Candida spp. (20.4 - $25.2 \mathrm{~mm})$, Prototheca spp. (20.8 - $30.0 \mathrm{~mm})$. From the three tested products, the best efficacy was found at the product no. $3\left(\mathrm{NHQ}-\mathrm{Cu}^{2+}-\mathrm{HAP}_{2}\right)$, followed by no. $1\left(\mathrm{HQ}-\mathrm{Cu}^{2+}-\mathrm{HAP}_{1}\right)$ and no. 2 $\left(\mathrm{HQ}-\mathrm{Cu}^{2+}-\mathrm{HAP}_{2}\right)$.

The inhibitory effect was bactericidal, manifested more intensively against Gram-positive bacteria, yeasts, and prototheca. Such products, prepared in the form of suspensions, may have practical application in the prevention and treatment of skin or hooves disorders. No resistance phenomena are recorded.
\end{abstract}

Keywords: copper, hydroxyapatite, hydroxyquinoline, microorganisms, sensitivity.

\section{INTRODUCTION}

Antibiotic therapy is nowadays experiencing major threats and antibiotic resistance of microorganisms to various pharmaceutical requires intensive research for an alternative solution. Although it is known for a long time that ions of metals ( $\mathrm{Ag}, \mathrm{Cu}, \mathrm{Zn}, \mathrm{Sr}$ and others) have antimicrobial properties, they have remained in obscurity in the heyday of antibiotics.

Hydroxyquinolines alone or complexed with various metal ions have demonstrated the ability to inhibit in vitro growth of various microorganisms, in particular bacteria and fungi, and the mechanism is represented by high 
lipophilicity which penetrates the membranes of the microbial cells by binding to metal ions of various enzymes. In such circumstances, a rupture of microbial cell walls and cell lysis occurs. In addition to this mechanism anti-inflammatory activity is revealed, a property useful in treating infectious diseases (Kim et al, 2005). An important aspect to be underlined is the fact that for these products no resistance phenomena as frequently occurs to antibiotics is observed. It underlines the importance of copper $\left(\mathrm{Cu}^{2+}\right)$ considered as a metal with multiple meanings (Scăețeanu and Pele, 2013), its antibacterial properties being highlighted in literature (Faúndez et al., 2004).

8 Hydroxyquinoline (8-HQ) is an organic compound with chemical formula $\mathrm{C}_{9} \mathrm{H}_{7} \mathrm{NO}$, molecular weight of $145.158 \mathrm{Da}$, and melting point of $75^{\circ} \mathrm{C}$. It is a quinoline derivative of a heterocyclic ring, by placing an $\mathrm{OH}$ group on the carbon 8 , which is 8-hydroxyquinoline (8HQ). It is a small molecule, flat (planar small molecule) with lipophilic effect and metal chelating ability. This substance has the appearance of an amorphous powder, a bright yellow appearance, soluble in alcohol, acetic acid, acetone, chloroform, benzene, ether, aqueous mineral acids and almost insoluble in water. 8-HQ was used in agriculture having insecticidal and preservative effect for textiles, wood, and paper industry, and in medicine for its antibacterial, antifungal, antiviral, anti-inflammatory and neuroprotective outcome (Anjaneyulu et al., 1982; Short et al., 2006; Prachayasittikul et al., 2013; Al-Busafi et al., 2014). 8-HQ antimicrobial activity is more intense in preparations with metal complexes (Kim et al., 1998; Srisung et al., 2013; Danistean et al., 2016).

In this paper, we aimed to investigate the antimicrobial effect of 8-HQ and its cooper derivatives, deposited on hydroxyapatite (HAP), prepared in three suspension versions. Compared to the antimicrobial activity of 8-HQ and cooper derivatives, we tested whether added HAP is conferring a strong dispersion and penetration, ensuring better bioactivity of the preparations designed.

\section{MATERIALS AND METHODS}

Data on tested products. The products were developed in the Laboratory for Nanobiomaterials Synthesis, Center of Physical Chemistry, Faculty of Chemistry and Chemical Engineering, UBB Cluj-Napoca, prepared in three versions: 1) HQ
$(4.1 \%)-\mathrm{Cu}^{2+}(3.5 \%)-\mathrm{HAP}_{1}$ (presynthesized); 2) $\mathrm{HQ}(4.5 \%)-\mathrm{Cu}^{2+}(8.2 \%)-\mathrm{HAP}_{2}$ (produced by synthesis); and 3) NHQ (5.1\%) - $\mathrm{Cu}^{2+}(8.1 \%)-$ $\mathrm{HAP}_{2}$ (produced by synthesis), where are NHQ stands for nitro-hydroxyquinoline.

The stoichiometric hydroxyapatite $\left(\mathrm{HAP}_{1}\right)$ powder was obtained at a molar ratio $\mathrm{Ca} / \mathrm{P}$ of 1.67 by a chemical precipitation method $[11,18,29$, $30,31]$. The already synthesized HAP1 powder was used for the adsorption of $\mathrm{HQ}, \mathrm{Cu}^{2+}$ ions, and of their $\mathrm{HQ}$ and $\mathrm{Cu}^{2+}$ self-assemblies. The $\mathrm{HAP}_{2}$ powder was directly synthesized during the preparation of self-assemblies of either HQ or NHQ with $\mathrm{Cu}^{2+}$ ions. As a consequence, the $\mathrm{HAP}_{2}$ can be doped with $\mathrm{Cu}^{2+}$, at least to a small percentage. This aspect will be investigated in future studies, to evaluate the efficacy of $\mathrm{HQ}$ and $\mathrm{NHQ}$, in the presence of $\mathrm{Cu}^{2+}$ ions, against various pathogens, using HAP as carriers for their local delivery.

The evaluation of the antimicrobial effect was performed in Microbiology Laboratory of the Faculty of Veterinary Medicine, University of Agricultural Sciences and Veterinary Medicine of Cluj-Napoca. The products had a greenish/bluish color due to copper, $\mathrm{pH}$ was 6.0 to 6.4 and liquid consistency in the form of suspensions which settle, but when stirred would mix evenly.

Data on microbial strains. Microbial strains that were tested are part of the following groups, respectively genera: Gram-negative bacteria (Escherichia, Salmonella); Gram-positive bacteria (Staphylococcus, Micrococcus, Bacillus); yeast (Candida) and unicellular algae (Prototheca). The selected strains were cultured for $24 \mathrm{~h}$ in glucose broth - obtaining the young cultures. The strains used in the test were isolated from clinical cases or from the environment and are part of the collection of Microbiology department, Faculty of Veterinary Medicine of Cluj-Napoca. In addition, international reference ATCC (American Type Culture Collection) strains were also used.

Working protocol. Microbial strains were inoculated on glucose culture media (nutrient broth and agar) (TM MEDIA TITAN BIOTECH, India), incubated at $37^{\circ} \mathrm{C}$ in aerobic conditions for $18-24$ hours (bacteria) and 48-72 hours (yeast and unicellular algae). The inhibitory effect was tested using antibiotic susceptibility by nutrient agar diffusion method according to CLSI standards, with the necessary adaptations for testing products in the form of suspensions. In this regard, the MHA 
was melted on a water bath and poured into Petri dishes with a diameter of $90 \mathrm{~mm}$ in an amount of $25 \mathrm{ml}$ to form a uniform layer with a thickness of $3 \mathrm{~mm}$.

The inoculation was performed by flooding, using $1 \mathrm{ml}$ of suspension of the strain tested with the optical density 0.5 on McFarland scale for bacteria and 1.0 for fungi and algae. The dispersion was evenly done and then the excess fluid was removed. Once the surface was dried, wells with a diameter of $6 \mathrm{~mm}$ were cut into the agar. The wells were filled with 2 to $20 \mu \mathrm{l} /$ well for each product used in the test, according to the protocol. The inoculated plates were incubated in a thermostat at $37^{\circ} \mathrm{C}$ for $18-24$ hours for bacteria and $48-72$ hours for yeasts and unicellular algae. The plates were evaluated regarding the presence/absence of colonies development around the wells. When the inhibitory effect was observed, the diameter of the inhibition areas was measured; the value being expressed in millimeters.

After this time the plates were read, assessing the presence or absence of cultural development around the wells. In the case of an inhibitory effect, the diameter of the inhibition zones has been measured, the value read being expressed in millimeters. The diffusion method used by us, has the advantage that in the absence of standard discs, can test liquids or suspensions, by practicing wells in nutrient agar, and filling being made with calibrated pipettes.

Preliminary tests were performed against various microbial strains using different amounts of products $(2 \mu \mathrm{l}, 5 \mu \mathrm{l}, 10 \mu \mathrm{l}$ and $20 \mu \mathrm{l} /$ well $)$ in order to estimate the amount that causes the inhibitory effect against diverse microorganisms. Subsequently, 25 strains were tested, 5 of each microbial genus: Staphylococcus, Micrococcus, Bacillus, Candida, and Prototheca; 4 strains from the collection of the Microbiology department and a reference ATCC strain (except for micrococci).

To determine whether the inhibitory effect is bactericidal or bacteriostatic, from the inhibition areas inoculations were performed in broth, followed by incubation at $37^{\circ} \mathrm{C}$ for 24 hours.

\section{RESULTS AND DISCUSSIONS}

1. The results according to the amount of products placed in the wells

Verification made with increasing amounts of products $(2 \mu \mathrm{l}, 5 \mu \mathrm{l}, 10 \mu \mathrm{l}$, and $20 \mu \mathrm{l})$ revealed that the inhibitory effect is correlated with the quantity deposited into the wells and especially with the group of tested microorganisms.

For Gram-negative bacteria, strains of Escherichia coli and Salmonella spp., none of the three products revealed inhibition areas, or they were very small, with narrow zones of inhibition of 8-10 $\mathrm{mm}$, seen in some $E$. coli strains.

On the other hand, against Gram-positive bacteria (Staphylococcus aureus, Bacillus cereus), yeasts (Candida albicans) and algae (Prototheca zopfii), it was found that all three tested products had a clear and intense inhibitory activity. The inhibitory effect is produced from $2 \mu \mathrm{l} /$ well and increases in intensity as the amount of product deposited in the wells increases; the largest zones of inhibition were observed for $20 \mu \mathrm{l} /$ well.

2. The results for HQ products against the reference strains and the strains isolated from clinical cases and the environment

Since previous tests revealed that HQ-based products exhibit a significant inhibitory effect on Gram-positive strains of bacteria, yeast, and algae, the next step was to test the sensitivity of strains belonging to the respective groups. The wells cut in the gel of nutrient agar plates were arranged in a triangular pattern, and in the central well of the plate was placed, as a control, the suspension of hydroxyapatite (HAP). The amount of product deposited in the wells was $20 \mu \mathrm{l} /$ well.

2.1. The result regarding the susceptibility of the genus Staphylococcus

The strain of Staphylococcus aureus ATCC $6538 \mathrm{P}$ and 4 other strains isolated from dairy cow mastitis were tested. The strains were identified based on morphological characters (cocci, Gram positive stain, grape shaped), catalase-positive, mannitol-positive. All strains produced hemolysis on blood agar. The results are summarized in Tab. 1.

By analyzing the data in Tab. 1 it can be seen that HQ based products have a good inhibitory effect on Staphylococcus.

In the case of product $1\left(\mathrm{HQ}-\mathrm{Cu}^{2+}-\mathrm{HAP}_{1}\right)$, the inhibition areas ranged between 20 to $22 \mathrm{~mm}$, the constant size of diameter for 4 strains was $22 \mathrm{~mm}$, and the fifth was $20 \mathrm{~mm}$; the average inhibition size was $21.6 \mathrm{~mm}$.

For product $2\left(\mathrm{HQ}-\mathrm{Cu}^{2+}-\mathrm{HAP}_{2}\right)$ the inhibition areas were smaller, between $16-18 \mathrm{~mm}$ and is also noted that the size for 4 strains was $18 \mathrm{~mm}$ in 
diameter and for the other was $16 \mathrm{~mm}$; average = $17.6 \mathrm{~mm}$.

For product $3\left(\mathrm{NHQ}-\mathrm{Cu}^{2+}-\mathrm{HAP}_{2}\right)$ inhibition areas were larger, between $20-24 \mathrm{~mm}$, with 24 $\mathrm{mm}$ for 4 strains and $20 \mathrm{~mm}$ for the fifth; average $=23.2 \mathrm{~mm}$.

The negative control (HAP) have not demonstrated inhibition activity.

The examination to determine whether the inhibitory effect was bactericidal or bacteriostatic showed that all three products had a bactericidal effect. In the inhibition area of the product 1 , there is a circular opaque area, which is due to the precipitation of components from the environment. No microorganisms were found in those areas, the control inoculation being sterile. Aspects of the inhibitory effect against Staphylococcus tested strains are presented in the Figures 1 ( $a$ and $b$ ).

\subsection{The result regarding the susceptibility of the genus Micrococcus}

There were tested five strains of M. luteus (lysodeikticus), from the collection of Microbiology Department, isolated from different secretions (nasal, conjunctival, auricular, milk). Samples were inoculated into broth and spread on agar and blood agar plates. The strains were identified

Tab. 1. The susceptibility of genus Staphylococcus

\begin{tabular}{|c|c|c|c|c|c|c|}
\hline \multirow[t]{2}{*}{ No } & \multirow{2}{*}{ Tested strains } & \multicolumn{3}{|c|}{$\begin{array}{c}\text { Products with } \mathrm{HQ} \\
\text { (inhibition areas } / \mathrm{mm} \text { ) }\end{array}$} & \multirow{2}{*}{$\begin{array}{c}\text { HAP } \\
\text { (control) }\end{array}$} & \multirow{2}{*}{ Effect } \\
\hline & & $\begin{array}{c}1 \\
\mathrm{HQ}-\mathrm{Cu}^{2+}-\mathrm{HAP} 1 \\
\end{array}$ & $\begin{array}{c}2 \\
\mathrm{HQ}-\mathrm{Cu}^{2+}-\mathrm{HAP} 2 \\
\end{array}$ & $\begin{array}{c}3 \\
\mathrm{NHQ}-\mathrm{Cu}^{2+}-\mathrm{HAP}_{2} \\
\end{array}$ & & \\
\hline 1 & $\begin{array}{c}\text { Staphylococcus aureus } \\
\text { ATCC } 6538 \mathrm{P}\end{array}$ & 22 & 18 & 24 & 0 & bactericidal \\
\hline 2 & Staphylococcus spp., 2 & 22 & 18 & 24 & 0 & bactericidal \\
\hline 3 & Staphylococcus spp., 3 & 22 & 18 & 22 & 0 & bactericidal \\
\hline 4 & Staphylococcus spp., 4 & 22 & 18 & 24 & 0 & bactericidal \\
\hline \multirow[t]{2}{*}{5} & Staphylococcus spp., 5 & 20 & 16 & 22 & 0 & bactericidal \\
\hline & $\begin{array}{l}\text { Average of the } \\
\text { inhibition area }\end{array}$ & 21.6 & 17.6 & 23.2 & 0 & \\
\hline
\end{tabular}
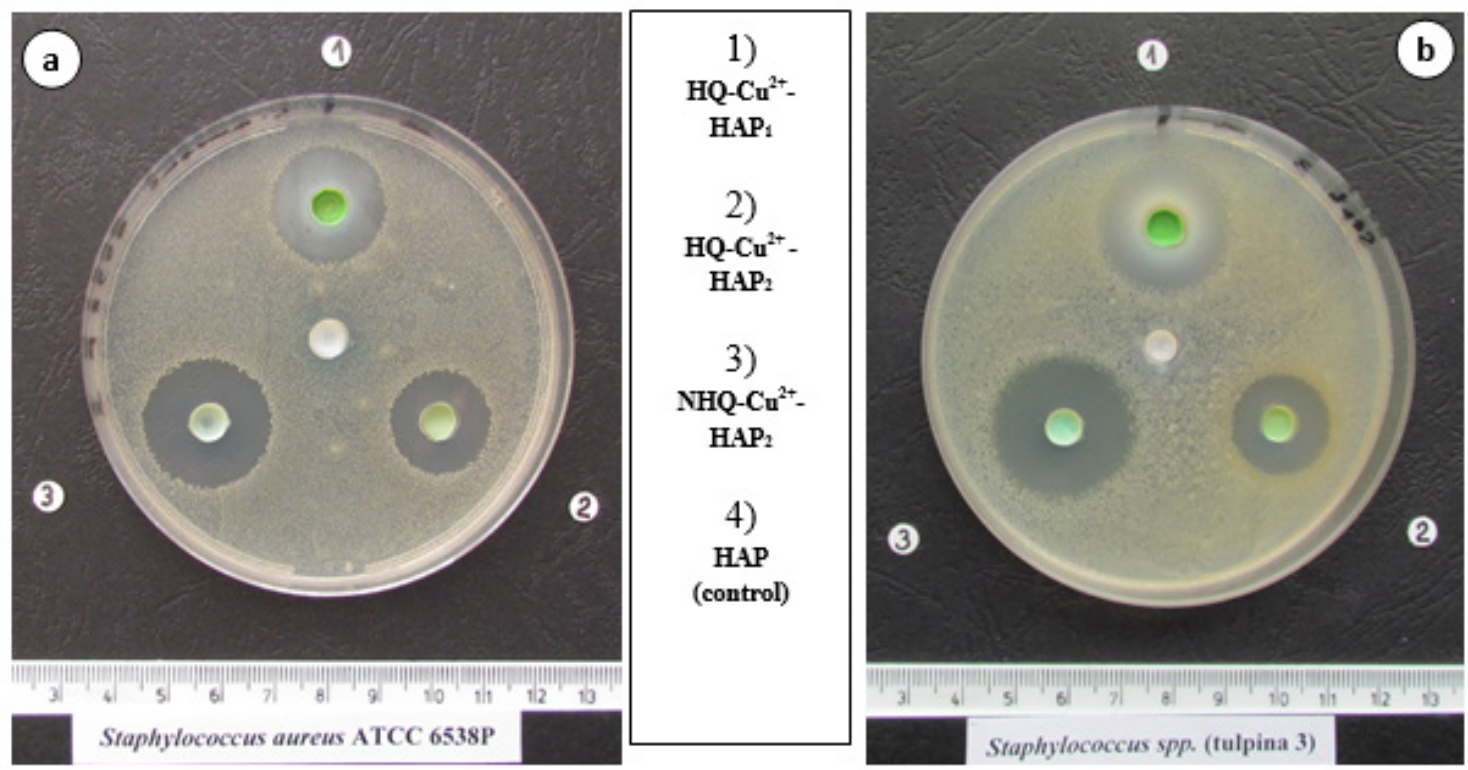

Fig. 1. Inhibition zones found in strains of the genus Staphylococcus 
based on morphological characters (cocci, Grampositive staining, diplo/tetrad grouping), catalasepositive, mannitol-negative. All strains were pigmented, with a bright yellow pigment. On blood agar, narrow areas of hemolysis are observed to some of the strains.

The inhibition areas have been large and well defined. Around the well containing the product 1 , there is a circular area of opacification, as also observed in staphylococci. On inspection was found that germs were not present because the inoculated tubes remained sterile. The results are summarized in Tab. 2.
Aspects of the inhibitory effect against Micrococcus tested strains are presented in the Figure $2(\mathrm{a}+\mathrm{b})$.

By analyzing the data in Tab. 2 it can be seen that HQ based products have a good inhibitory effect on Micrococcus strains.

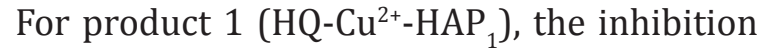
areas ranged between 20 to $30 \mathrm{~mm}$, with the following values: strain 1 (28 mm); strain 2 (20 $\mathrm{mm})$, strain $3(30 \mathrm{~mm})$, strain $4(22 \mathrm{~mm})$ and strain $5(26 \mathrm{~mm})$; the average inhibition size was $25.2 \mathrm{~mm}$.

Tab. 2. The susceptibility of genus Micrococcus

\begin{tabular}{|c|c|c|c|c|c|c|}
\hline \multirow[t]{2}{*}{ No } & \multirow{2}{*}{ Tested strains } & \multicolumn{3}{|c|}{$\begin{array}{c}\text { Products with HQ } \\
\text { (inhibition areas } / \mathrm{mm} \text { ) }\end{array}$} & \multirow{2}{*}{$\begin{array}{c}\text { HAP } \\
\text { (control) }\end{array}$} & \multirow{2}{*}{ Effect } \\
\hline & & $\begin{array}{c}1 \\
\mathrm{HQ}-\mathrm{Cu}^{2+}-\mathrm{HAP}_{1}\end{array}$ & $\begin{array}{c}2 \\
\mathrm{HQ}-\mathrm{Cu}^{2+}-\mathrm{HAP}_{2} \\
\end{array}$ & $\begin{array}{c}3 \\
\mathrm{NHQ}-\mathrm{Cu}^{2+}-\mathrm{HAP}_{2} \\
\end{array}$ & & \\
\hline 1 & $\begin{array}{l}\text { Micrococcus luteus } \\
\quad(\text { lysodeikticus })\end{array}$ & 28 & 20 & 30 & 0 & bactericidal \\
\hline 2 & Micrococcus spp. 2 & 20 & 16 & 24 & 0 & bactericidal \\
\hline 3 & Micrococcus spp. 3 & 30 & 20 & 32 & 0 & bactericidal \\
\hline 4 & Micrococcus spp. 4 & 22 & 18 & 24 & 0 & bactericidal \\
\hline \multirow[t]{2}{*}{5} & Micrococcus spp. 5 & 26 & 24 & 28 & 0 & bactericidal \\
\hline & $\begin{array}{l}\text { Average of the } \\
\text { inhibition area }\end{array}$ & 25.2 & 19.6 & 27.6 & & \\
\hline
\end{tabular}
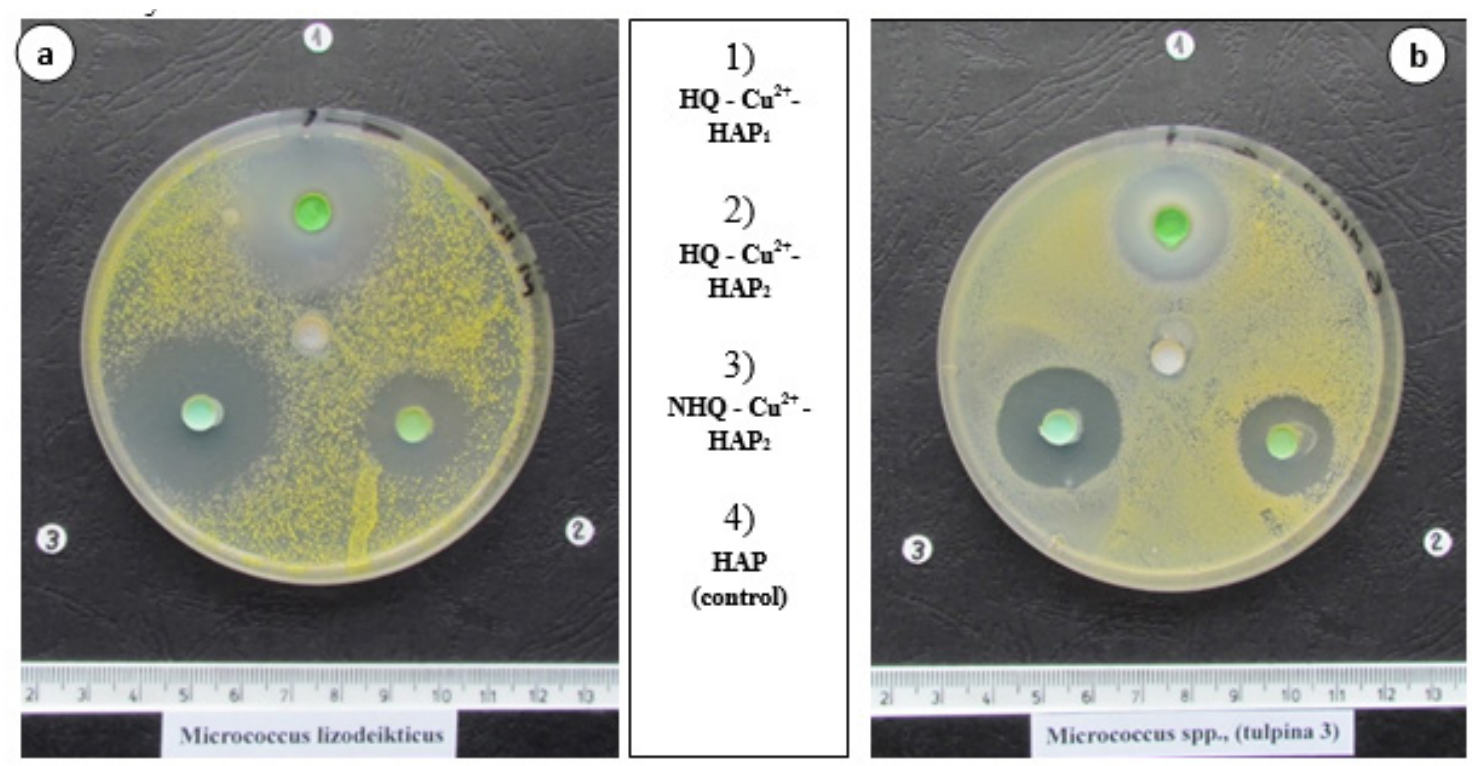

Fig. 2. Inhibition zones found for strains of the Micrococcus genus 
For product $2\left(\mathrm{HQ}-\mathrm{Cu}^{2+}-\mathrm{HAP}_{2}\right)$ the inhibition areas were smaller, between 16-24 mm: strain $1(20 \mathrm{~mm})$, strain $2(16 \mathrm{~mm})$, strain $3(20 \mathrm{~mm})$, strain $4(18 \mathrm{~mm})$ and strain $5(24 \mathrm{~mm})$; average $=$ $19.6 \mathrm{~mm}$.

For product $3\left(\mathrm{NHQ}-\mathrm{Cu}^{2+}-\mathrm{HAP}_{2}\right)$ inhibition areas were the largest - 24-32 mm: strain 1 (30 $\mathrm{mm})$, strain $2(24 \mathrm{~mm})$, strain $3(32 \mathrm{~mm})$, strain $4(24 \mathrm{~mm})$ and strain $5(28 \mathrm{~mm})$; average $=27.6$ $\mathrm{mm}$.

\subsection{The result regarding the susceptibility of the genus Bacillus}

We tested a reference strain of Bacillus cereus ATCC 14579, and 4 strains from the Microbiology Department collection, isolated from various sources, mainly from mastitic milk. The strains were inoculated on common culture media, and onto an egg-based medium to highlight the ability to produce lecithinase.

The strains showed typical morphological and cultural characters for Bacillus cereus. The results are summarized in Tab. 3.

By analyzing the data in Tab. 3 it can be seen that HQ based products have a good inhibitory effect on Bacillus cereus strains.

To the product $1\left(\mathrm{HQ}-\mathrm{Cu}^{2+}-\mathrm{HAP}_{1}\right)$, the inhibition areas ranged between 12 to $20 \mathrm{~mm}$, with the following values: reference strain $(20 \mathrm{~mm})$; strain $2(18 \mathrm{~mm})$, strain $3(12 \mathrm{~mm})$, strain $4(14 \mathrm{~mm})$ and the strain $5(14 \mathrm{~mm})$; the average inhibition size was $15.6 \mathrm{~mm}$. It can notice the existence of a circular area of opacity, but the germs are absent because the inoculation in control tubes (glucose broth) was sterile.

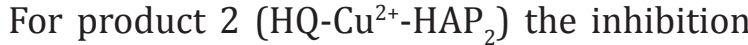
areas were smaller, between $10-20 \mathrm{~mm}$ : strain $1(20 \mathrm{~mm})$, strain $2(16 \mathrm{~mm})$, strain $3(12 \mathrm{~mm})$, strain $4(12 \mathrm{~mm})$ and strain $5(10 \mathrm{~mm})$; average $=$ $14.0 \mathrm{~mm}$.

For product $3\left(\mathrm{NHQ}-\mathrm{Cu}^{2+}-\mathrm{HAP}_{2}\right)$ inhibition zones were larger, ranging between 14 and 24 $\mathrm{mm}$ : strain $1(24 \mathrm{~mm})$, strain $2(22 \mathrm{~mm})$, strain 3 (14 mm), strain $4(14 \mathrm{~mm})$ and strain $5(16 \mathrm{~mm})$; average $=18.0 \mathrm{~mm}$.

Aspects of the inhibitory effect against $B$. cereus tested strains are presented in the fig. 3 (a $+b)$.

\subsection{The result regarding the susceptibility of the genus Candida}

We tested one reference strain (ATCC 90028) and 4 strains available in the collection of Microbiology Department, being isolated from various sources (oral cavity, mastitic milk, skin lesions). Inoculation was initially done in glucose broth, followed by passage on glucose agar and Sabouraud medium. Upon bacterioscopic examination, all tested strains showed typical morphology: ovoid shape, 3/5-6 $\mu \mathrm{m}$ in size, with characteristic burgeoning appearance. The results are summarized in Tab. 4.

By analyzing the data in Tab. 4 it can be seen that HQ based products have a good inhibitory effect on genus Candida yeasts, even if they belonged to different species.

Tab. 3. The susceptibility of Bacillus cereus strains

\begin{tabular}{|c|c|c|c|c|c|c|}
\hline \multirow[t]{2}{*}{ No } & \multirow{2}{*}{ Tested strains } & \multicolumn{3}{|c|}{$\begin{array}{c}\text { Products with HQ } \\
\text { (inhibition areas } / \mathrm{mm} \text { ) }\end{array}$} & \multirow{2}{*}{$\begin{array}{c}\text { HAP } \\
\text { (control) }\end{array}$} & \multirow{2}{*}{ Effect } \\
\hline & & $\begin{array}{c}1 \\
\mathrm{HQ}-\mathrm{Cu}^{2+}-\mathrm{HAP}_{1}\end{array}$ & $\begin{array}{c}2 \\
\mathrm{HQ}-\mathrm{Cu}^{2+}-\mathrm{HAP}_{2} \\
\end{array}$ & $\begin{array}{c}3 \\
\mathrm{NHQ}-\mathrm{Cu}^{2+}-\mathrm{HAP}_{2} \\
\end{array}$ & & \\
\hline 1 & $\begin{array}{c}\text { Bacillus cereus } \\
\text { ATCC } 14579\end{array}$ & 20 & 20 & 24 & 0 & bactericidal \\
\hline 2 & Bacillus cereus 2 & 18 & 16 & 22 & 0 & bactericidal \\
\hline 3 & Bacillus cereus 3 & 12 & 12 & 14 & 0 & bactericidal \\
\hline 4 & Bacillus cereus 4 & 14 & 12 & 14 & 0 & bactericidal \\
\hline \multirow[t]{2}{*}{5} & Bacillus cereus 5 & 14 & 10 & 16 & 0 & bactericidal \\
\hline & $\begin{array}{l}\text { Average of the } \\
\text { inhibition area }\end{array}$ & 15.6 & 14.0 & 18.0 & & \\
\hline
\end{tabular}


For product $1\left(\mathrm{HQ}^{-} \mathrm{Cu}^{2+}-\mathrm{HAP}_{1}\right)$, the inhibition areas ranged between 22 to $28 \mathrm{~mm}$, with the following values: strain $1(28 \mathrm{~mm})$; strain 2 (22 $\mathrm{mm})$, strain $3(24 \mathrm{~mm})$, strain $4(22 \mathrm{~mm})$ and strain $5(24 \mathrm{~mm})$; the average inhibition size was $24.0 \mathrm{~mm}$.

To the product $2\left(\mathrm{HQ}-\mathrm{Cu}^{2+}-\mathrm{HAP}_{2}\right)$, the inhibition areas ranged between 18 to $26 \mathrm{~mm}$ : strain 1 (26 mm), strain 2 (18 mm), strain 3 (20 $\mathrm{mm})$, strain $4(18 \mathrm{~mm})$ and strain $5(20 \mathrm{~mm})$; average $=20.4 \mathrm{~mm}$.
For product $3\left(\mathrm{NHQ}-\mathrm{Cu}^{2+}-\mathrm{HAP}_{2}\right)$ inhibition zones were the largest, ranging between 24 to 30 $\mathrm{mm}$ : strain $1(30 \mathrm{~mm})$, strain $2(24 \mathrm{~mm})$, strain 3 (28 mm), strain $4(24 \mathrm{~mm})$ and strain $5(26 \mathrm{~mm})$; average $=26.4 \mathrm{~mm}$.

It can be shown that against Candida strains a good inhibitory efficacy was recorded, the inhibition areas being large, well delineated. We note that in the case of some Candida strains, an opacity area is present around the well with product 1 , but without the presence of living cell because the control inoculation appears to be

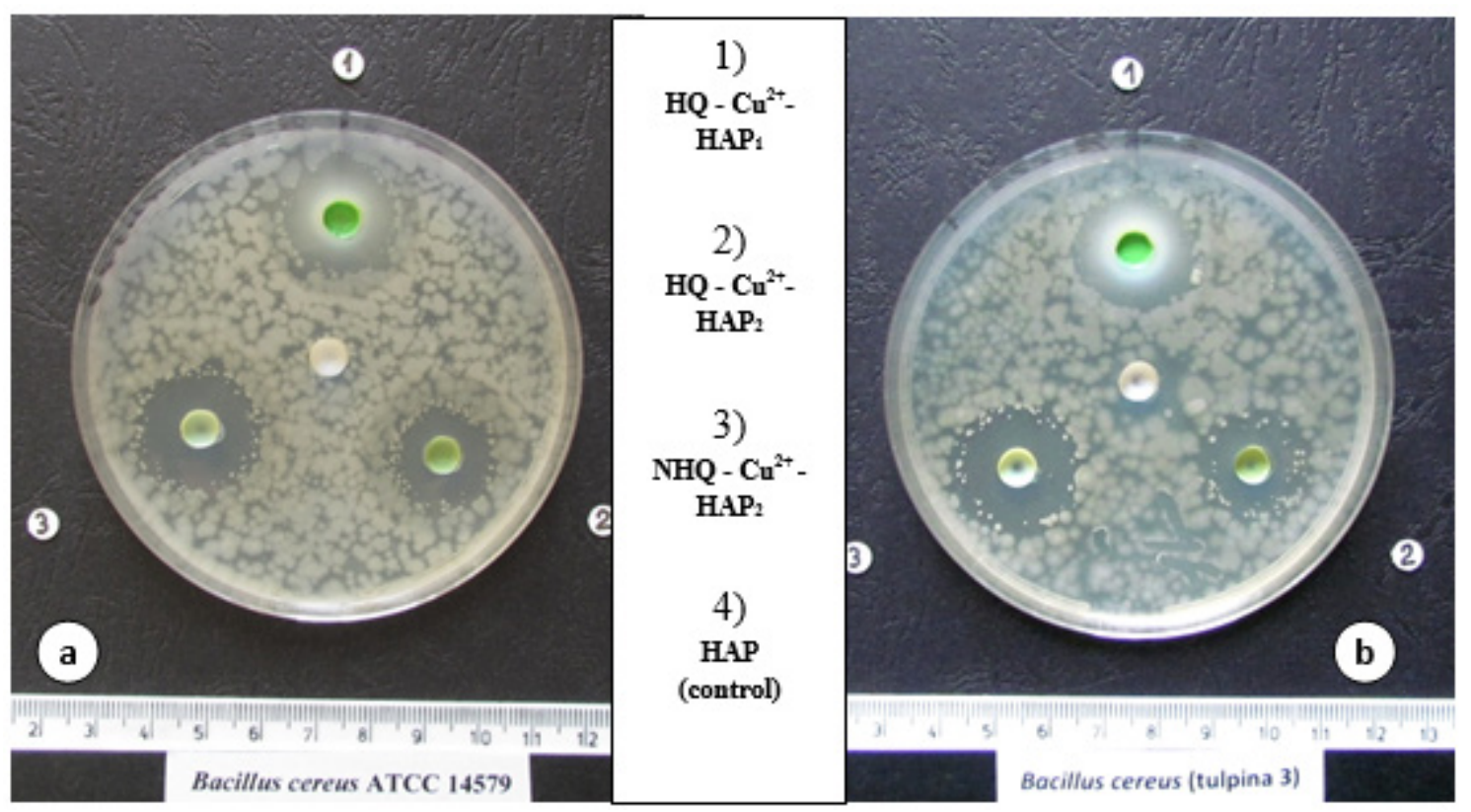

Fig. 3. Inhibition areas found in B. cereus strains

Tab. 4. The susceptibility of genus Candida

\begin{tabular}{|c|c|c|c|c|c|c|}
\hline \multirow[t]{2}{*}{ No } & \multirow{2}{*}{ Tested strains } & \multicolumn{3}{|c|}{$\begin{array}{c}\text { Products with } \mathrm{HQ} \\
\text { (inhibition areas } / \mathrm{mm} \text { ) }\end{array}$} & \multirow{2}{*}{$\begin{array}{c}\text { HAP } \\
\text { (control) }\end{array}$} & \multirow{2}{*}{ Effect } \\
\hline & & $\begin{array}{c}1 \\
\mathrm{HQ}-\mathrm{Cu}^{2+}-\mathrm{HAP}_{1} \\
\end{array}$ & $\begin{array}{c}2 \\
\mathrm{HQ}-\mathrm{Cu}^{2+}-\mathrm{HAP}_{2} \\
\end{array}$ & $\begin{array}{c}3 \\
\mathrm{NHQ}-\mathrm{Cu}^{2+}-\mathrm{HAP}_{2} \\
\end{array}$ & & \\
\hline 1 & $\begin{array}{l}\text { Candida albicans } \\
\text { ATCC } 90028\end{array}$ & 28 & 26 & 30 & 0 & fungicidal \\
\hline 2 & Candida kefyr & 22 & 18 & 24 & 0 & fungicidal \\
\hline 3 & Candida albicans 1 & 24 & 20 & 28 & 0 & fungicidal \\
\hline 4 & Candida albicans 2 & 22 & 18 & 24 & 0 & fungicidal \\
\hline \multirow[t]{2}{*}{5} & Candida albicans 3 & 24 & 20 & 26 & 0 & fungicidal \\
\hline & $\begin{array}{l}\text { Average of the } \\
\text { inhibition area }\end{array}$ & 24.0 & 20.4 & 26.4 & & \\
\hline
\end{tabular}


sterile. Control product (HAP) shows no inhibitory effect.

Aspects of the inhibitory effect against Candida strains are presented in fig. $4(a+b)$.

\subsection{The result regarding the susceptibility of Prototheca strains}

We tested a reference strain of Prototheca wickerhamii (ATCC 16529) and 4 strains of Prototheca zopfii from the collection of the Microbiology Department, isolated from mastitic milk. Cultivation was carried out on glucose culture media, and colonies occurred in 48-72 hours, with characteristic features (3-4 $\mathrm{mm}$ diameter, white, matte, slightly lobed edges, granular surface with cauliflower appearance). When examining the wet smears in Lugol solution, all strains showed typical morphology for Prototheca, round shape with dimensions of 6-20 $\mu \mathrm{m}$ for $P$. wickerhamii, and ovoid shape with $20-30 \mu \mathrm{m}$ size for $P$. zopfii, and with the presence of endospores, that is a characteristic feature for this algae. The results are summarized in Tab. 5.

By analyzing the data in Tab. 5 it can be seen that HQ based products have a good inhibitory effect on Prototheca algae.

For product $1\left(\mathrm{HQ}-\mathrm{Cu}^{2+}-\mathrm{HAP}_{1}\right)$, the inhibition areas ranged between 26 to $34 \mathrm{~mm}$, the constant
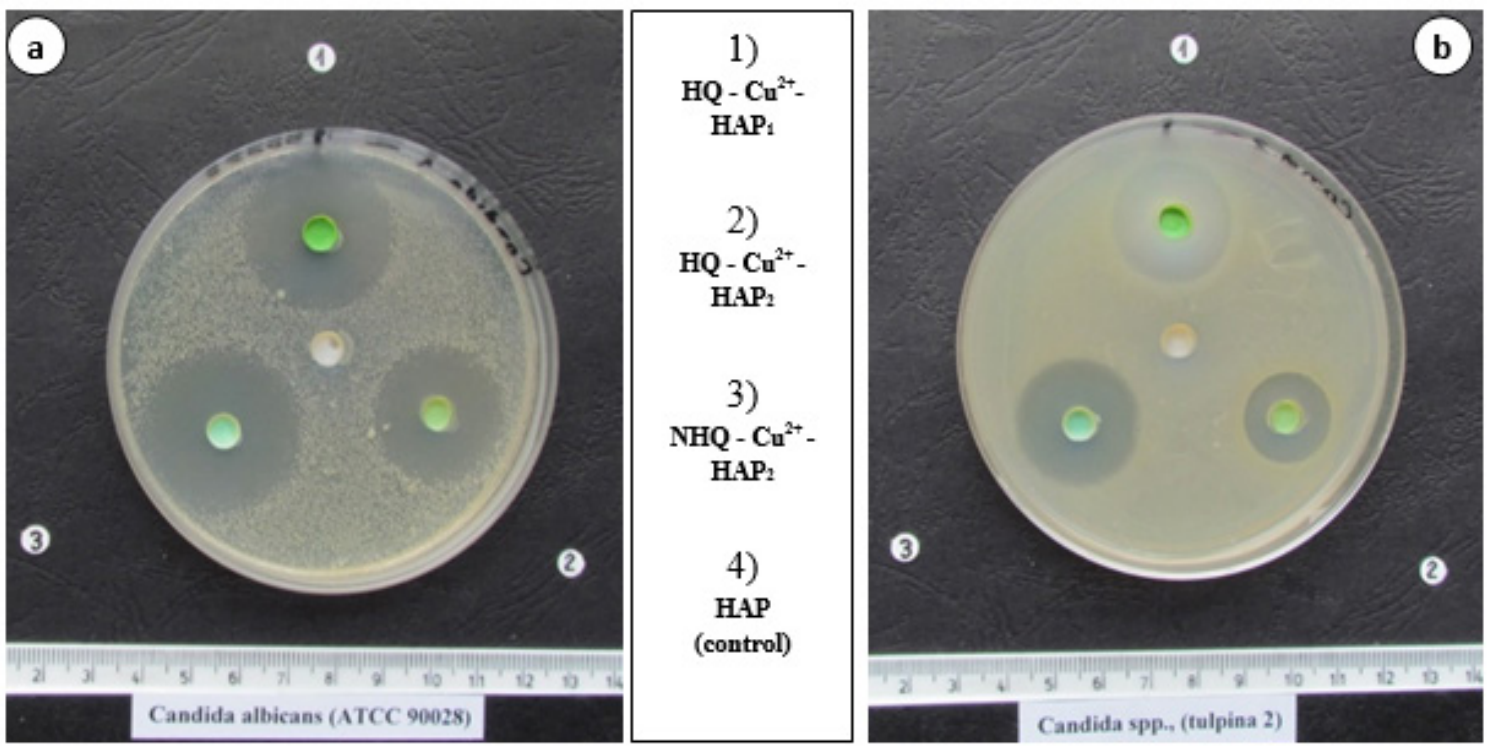

Fig. 4. Inhibition areas found for strains of the Candida genus.

Tab. 5. The susceptibility of genus Prototheca

\begin{tabular}{|c|c|c|c|c|c|c|}
\hline \multirow[t]{2}{*}{ No } & \multirow{2}{*}{ Tested strains } & \multicolumn{3}{|c|}{$\begin{array}{c}\text { Products with HQ } \\
\text { (inhibition areas } / \mathrm{mm} \text { ) }\end{array}$} & \multirow{2}{*}{$\begin{array}{c}\text { HAP } \\
\text { (control) }\end{array}$} & \multirow{2}{*}{ Effect } \\
\hline & & 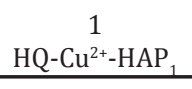 & $\begin{array}{c}2 \\
\mathrm{HQ}-\mathrm{Cu}^{2+}-\mathrm{HAP}_{2} \\
\end{array}$ & $\begin{array}{c}3 \\
\text { NHQ- } \mathrm{Cu}^{2+}-\mathrm{HAP}_{2} \\
\end{array}$ & & \\
\hline 1 & Prototheca zopfii 1 & 26 & 20 & 30 & 0 & algicidal \\
\hline 2 & Prototheca zopfii 2 & 26 & 18 & 28 & 0 & algicidal \\
\hline 3 & Prototheca zopfii 3 & 26 & 18 & 28 & 0 & algicidal \\
\hline 4 & Prototheca zopfii 4 & 26 & 18 & 28 & 0 & algicidal \\
\hline \multirow[t]{2}{*}{5} & $\begin{array}{l}\text { P. wickerhamii } \\
\text { ATCC } 16529\end{array}$ & 34 & 30 & 36 & 0 & algicidal \\
\hline & $\begin{array}{l}\text { Average of the } \\
\text { inhibition area }\end{array}$ & 27.6 & 20.8 & 30.0 & & \\
\hline
\end{tabular}


size of diameter for 4 strains was $26 \mathrm{~mm}$, and the fifth was larger (34 $\mathrm{mm}$ ); the average inhibition size being $27.6 \mathrm{~mm}$.

To the product $2\left(\mathrm{HQ}-\mathrm{Cu}^{2+}-\mathrm{HAP}_{2}\right)$, the inhibition areas ranged between 18 to $30 \mathrm{~mm}$ : is constant in size for P. zopfii: strain $1(20 \mathrm{~mm})$ and strains 2, 3 and 4 (18 $\mathrm{mm})$, and to the strain $P$. wickerhamii the area of inhibition was higher (30 $\mathrm{mm}$ ); average $=20.8 \mathrm{~mm}$.

For product $3\left(\mathrm{NHQ}-\mathrm{Cu}^{2+}-\mathrm{HAP}_{2}\right)$ inhibition zones were the largest, ranging between 28 to 36 mm. For P. zopfii: strain 1 (30 mm), strains 2, 3, 4 $(28 \mathrm{~mm})$. For $P$. wickerhamii strain the inhibition area was larger (36 $\mathrm{mm}$ ); the average inhibition size being $30.0 \mathrm{~mm}$. Aspects regarding growth inhibition of Prototheca strains are shown in figure $5(\mathrm{a}+\mathrm{b})$.

Hydroxyquinoline-based preparations in combination with copper pentahydrate deposited on hydroxyapatite were tested in order to determine the ability to inhibit the in vitro growth of some bacterial strains (Gram positive and Gram negative), yeasts and unicellular algae.

Initial testing carried out by distribution in the wells of increasing amounts of each product ( 2 $\mu \mathrm{l}, 5 \mu \mathrm{l}, 10 \mu \mathrm{l}$ and $20 \mu \mathrm{l}$ ) has been found that Gram negative bacteria (Escherichia coli, Salmonella typhimurium) proved to be less sensitive or not inhibited. Lower sensitivity of Gram-negative bacteria has been reported by other research specified in the investigated literature (Shen et al., 1999; Okide et al., 2000; Al-Busafi et al., 2014). Gram-positive bacteria were found to be more sensitive, inhibition zones were recorded for all of the products. The inhibitory effect is produced starting with $2 \mu \mathrm{l} /$ well, and increases in intensity as the amount of product deposited in the wells also increases. After this first stage of the investigations, it has been observed that the best efficacy has product no. 3 (NHQ- $\mathrm{Cu}^{2+}-\mathrm{HAP}_{2}$ ), and the amount that make the largest zones of inhibition is $20 \mu \mathrm{l} /$ well. We believe that differences in sensitivity between the two groups of bacteria is probably due to differences in the structure of the cell wall, which for Gram negative bacteria is thinner but more complex, and for the Gram positive is thicker, but structurally much simpler.

By analyzing the inhibitory effect induced by the tested products against microbial strains, grouped by genre (Staphylococcus, Micrococcus, Bacillus, Candida and Prototheca), and taking as a basis the average value of the diameters of the inhibition areas, it can be shown that the growth of all the strains was inhibited (Tab. 6).

Depending on the average value of the diameters of the inhibition zones, of the strains placed in genres (horizontal columns), it can be seen that the sensitivity has an average value scale in descending order as follow: Prototheca (26.13 $\mathrm{mm}$ ), Micrococcus (24.13 mm) Candida (23.60 $\mathrm{mm})$, Staphylococcus (20.80 $\mathrm{mm})$ and Bacillus (15.88 mm).
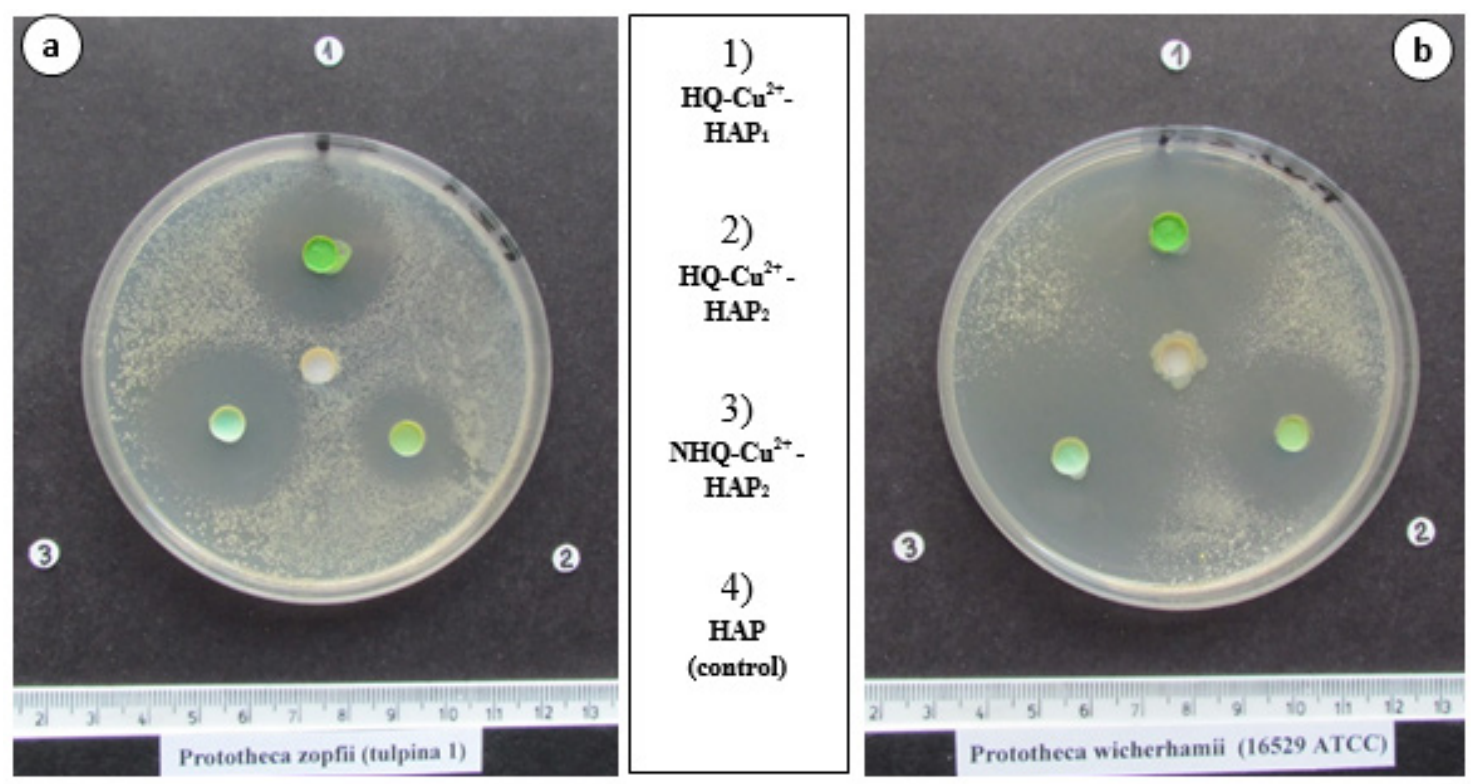

Fig. 5. Inhibition zones found for strains of the Prototheca genus. 
Depending on the average value of the diameters of the zones of inhibition induced by each of the three products (vertical columns) efficacy was framed in the following scale of values in descending order: the most intensive inhibitory activity was recorded to the product no. $3\left(\mathrm{NHQ}-\mathrm{Cu}^{2+}-\mathrm{HAP}_{2}\right)(25.04 \mathrm{~mm})$, followed by the product no. $1\left(\mathrm{HQ}-\mathrm{Cu}^{2+}-\mathrm{HAP}_{1}\right)(22.8 \mathrm{~mm})$ and by the product $2\left(\mathrm{HQ}-\mathrm{Cu}^{2+}-\mathrm{HAP}_{2}\right)(18.48 \mathrm{~mm})$.

The fact that $8 \mathrm{HQ}$ have good efficacy against Staphylococcus strains is also underlined by other authors. In a study performed on 213 strains of Staphylococcus strains, using an aqueous preparation containing $0.5 \%$ hydroxyquinoline $(\mathrm{AQ}+)$ it was found that the preparation was shown to strongly inhibit the growth of all isolates with a median MIC of $0.25 \%$ at an optimum $\mathrm{pH}$ of 9.2. It is also mentioned that lowering the $\mathrm{pH}$ to 7.5 will gave a 4 -fold reduction in efficacy and at $\mathrm{pH}$ 5.5 there is an approximately 8 -fold reduction in efficacy (Short et al., 2006). The same researchers show that MRSA strains as well as vancomycinintermediate strains are equally susceptible to $\mathrm{AQ}+$ as methicillin-susceptible $S$. aureus. The TEM technique (Transmission Electron Microscopy) prove that $\mathrm{AQ}+$ actively disrupts the cell wall of $S$. aureus and therefore leading to cell lysis. Such results demonstrate that $\mathrm{AQ}+$ has strong antimicrobial activity and is possible to be useful in formulas that will reduce nasal and skin carriage of MRSA (Short et al., 2006).

The efficacy of 8-HQ against $S$. aureus is dependent on the chelating ability, and is enhanced by the presence of copper (Pavolov et al., 2011). It is noted that some derivatives of 8-HQ have greatly enhanced antimicrobial activity in the presence of copper (Rohde et al., 1976). Inhibitory effect was also found in intestinal bacteria, both aerobic (E. coli, Lactobacillus acidophilus, Lactobacillus casei, Bifidobacterium longum) and anaerobic (Clostridium difficile, Clostridium perfringens) (Jeon et al., 2009). It has been found that 8-HQ has an inhibiting effect against Mycobacterium tuberculosis (Darby et Nathan, 2010). Complexation of derivatives of 8-HQ with $\mathrm{Cu}$ and $\mathrm{Ni}$ improves antimicrobial activity, as demonstrated for the Staphylococcus aureus, Proteus vulgaris, Pseudomonas aeruginosa and Klebsiella pneumoniae strains (Vashi et Sheth, 2013). The inhibitory activity was also demonstrated for Mycoplasma and Ureaplasma strains, isolated from urinary tract infections (Bonissol et al., 1986).

Regarding the mechanism of action, 8-HQ and its derivatives are effective against Gram positive bacteria and less effective against Gram negative (Shen et al., 1999; Okidata et al., 2000). It is also found that 8-HQ has high lipophilicity and has the ability to penetrate the bacterial cell membranes, possibly by binding the metal ions with the bacterial enzymes (Albert et al., 1953). 8 HQ complexation with sulfanilamide enhances antimicrobial activity against Gram positive bacteria, the complex is more active than the individual components taken separately (Shen et al., 1999). Hydroxyquinoline based products are also active against yeasts (Candida albicans, $C$. tropicalis, C. krusei and Torulopsis glabrata) (Cancet

Tab. 6. The average value of the inhibition zones

\begin{tabular}{cccccc}
\hline \multirow{2}{*}{ No } & Tested strains & \multicolumn{3}{c}{$\begin{array}{c}\text { Products with } \mathrm{HQ} \\
\text { (inhibition areas/mm) }\end{array}$} & $\begin{array}{c}\text { Average } \\
\text { (by strains) }\end{array}$ \\
\cline { 3 - 5 } & Staphylococcus spp. & $\begin{array}{c}1 \\
\mathrm{HQ}^{2+}-\mathrm{Cu}^{++}-\mathrm{HAP}_{1}\end{array}$ & $\begin{array}{c}2 \\
\mathrm{HQ}^{2+} \mathrm{Cu}^{++}-\mathrm{HAP}_{2}\end{array}$ & $\begin{array}{c}3 \\
\mathrm{NHQ}^{2+} \mathrm{Cu}^{2+}-\mathrm{HAP}_{2}\end{array}$ & \\
\hline 1 & 21.6 & 17.6 & 23.2 & 20.80 \\
\hline 2 & Micrococcus spp., & 25.2 & 19.6 & 27.6 & 24.13 \\
\hline 3 & Bacillus spp. & 15.6 & 14.0 & 18.0 & 15.86 \\
\hline 4 & Candida spp. & 24.0 & 20.4 & 26.4 & 23.60 \\
\hline 5 & Prototheca spp, & 27.6 & 20.8 & 30.0 & 26.13 \\
\hline & Average (by products) & 21.6 & 17.6 & 23.2 & 20.80 \\
\hline
\end{tabular}


et al., 1987), molds (Aspergillus spp.) (Vanparia et al., 2010; Al-Busaf et al., 2014), some parasites (Trichomonas) (Bergogne-Berezin et al., 1987) and agent of malaria (Plasmodium falciparum) (Adler et Scheibel, 1982; Biswas, 2003). Literature also mentions an antiviral effect (Rohde et al., 1976); (Kassem et al., 2012). Several chelating agents have been investigated for their potential in the treatment of neurodegenerative diseases, a series of 8-hydroxyquinoline analogs have been shown to have great potential in the treatment of such diseases, eg. Alzheimer's, Parkinson's and multiple sclerosis (Budimir, 2011), the anticancer (Ruiz-Azuara et al., 2010), antioxidant and antiinflammatory (Kim et al., 2005) and antidiabetic effects (Prachayasittikul et al., 2013). The products have found application in veterinary medicine in the treatment of otitis in dogs and cats (Maestrone et al., 1979), or some digital papilloma in cattle (Britt et al., 1996).

We believe that the results of the research resumed in this paper confirm the antimicrobial ability of tested products based on hydroxyquinoline and cupric derivatives in combination with hydroxyapatite. It has been demonstrated that the antimicrobial spectrum is broad, intense and bactericidal against strains of Staphylococcus, Micrococcus, Bacillus, but is even more intense over the genus Candida and Prototheca. The addition of hydroxyapatite increases the activity of these preparations, ensuring a better dispersion and persistence of the products.

\section{CONCLUSIONS}

Products based on hydroxyquinoline and cupric derivatives deposited on hydroxyapatite, showed an intense antimicrobial activity against Gram positive bacteria (Staphylococcus, Micrococcus, Bacillus), yeast (Candida), unicellular algae (Prototheca) and lower activity against Gram-negative bacteria (Escherichia, Salmonella).

Heavily inhibitory effect against all tested microorganisms was recorded for the product 3 $\left(\mathrm{NHQ}-\mathrm{Cu}^{2+}-\mathrm{HAP}_{2}\right.$ ), followed by the product 1 (HQ$\left.\mathrm{Cu}^{2+}-\mathrm{HAP}_{1}\right)$, and product $2\left(\mathrm{HQ}-\mathrm{Cu}^{2+}-\mathrm{HAP}_{2}\right)$, the effect being bactericidal, algicidal and fungicidal.

Such products, prepared in the form of suspensions, may have practical application in the prevention and treatment of skin or hooves disorders, when isolated microbiota is sensitive to hydroxyquinoline compounds.

Acknowledgments: The authors acknowledge funding by the UEFISCDI through the grant no. 257.

\section{REFERENCES}

1. Albert A, Gibson MI, Rubbo SD (1953). The influence of chemical constitution on antibacterial activity VI The bactericidal action of 8-Hydroxyquinoline (Oxine) $\mathrm{Br} \mathrm{J}$ Exp Pathol 34(2): 119-130.

2. Al-Busafi NS, Suliman FE, Al-Alawi RZ (2014). 8-Hydroxyquinoline and Its Derivates: Syntesis and Applications. Journal of Chemistry 3(1): 1-8.

3. Anjaneyulu Y, Rao RP, Swamy RY, Eknath A, Rao KN (1982). In vitro antimicrobial-activity studies on the mixed ligand complexes of $\mathrm{Hg}$ (II) with 8-hydroxyquinolone and salicylic acids. Proc Indian Acad Sci (Chem Sci) 91(2): 157-163.

4. Bergogne-Berezin E, Berthelot G, Muller-Serieys C (1987). Present status of nitoxoline. Pathol Biol (Paris) 35(5 Pt 2): 873-878.

5. Biswas S (2003). 8-Hydroxyquinoline inhibits the multiplication of Plasmodium falciparum in vitro. Ann Trop Med Parasitol 97(5): 527-530.

6. Bonissol C, Pua K, Stoiljkovic B (1986). In vitro activity of nitroxoline on urogenital mycoplasmas. Pathol Biol (Paris) 34(9): 1001-1005.

7. Britt JS, Gaska J, Garrett EF, Konkle D, Mealy M (1996). Comparison of topical application of three products for treatment of papillomatous digital dermatitis in dairy cattle. J Am Vet Med Assoc 209(6): 1134-1136.

8. Budimir A (2011). Metal ions, Alzheimer's disease and chelation therapy Acta Pharm, 61(1):1-14

9. Cancet B, Amgar A (1987). In vitro antifungal activity of nitroxoline Preliminary clinical results. Pathol Biol (Paris) 35(5 Pt 2): 879-881.

10. Darby CM, Nathan CF (2010). Killing of non-replicating Mycobacterium tuberculosis by 8- hydroxyquinoline. J Antimicrob Chemother 65(7): 1424-1427.

11. Danistean A, Gorea M, Avram A, Rapuntean S, Tomoaia Gh, Mocanu A, Garbo C, Horovitz O, Tomoaia-Cotisel M (2016). Antimicrobial activity of ceramic disks loaded with silver ions and nitoxoline. Studia Univ Babes-Bolyai Chem 61 (3): 275-283.

12. Jeon JH, Lee CH, Lee HS (2009). Antimicrobial activities od 2-methyl-8-hydroxyquinoline and its derivatives against human intestinal bacteria. J Korean Soc Appl Biol Chem 52(2): 202-205.

13. Faúndez G, Troncoso M, Navarrete P, Figueroa G (2004). Antimicrobial activity of cooper surface against suspensions of Salmonella enterica and Campylobacter jejuni. BMC Microbiology DOI: 101186.

14. Kassem EM, El-Sawy ER, Abd-Alla HI, Mandour AH, AbdelMogeed D, El-Safty MM (2012). Synthesis, antimicrobial, and antiviral activities of some new 5-sulphonamido- 
8-hydroxyquinoline derivatives. Arch Pharm Res 35(6): 955-964.

15. Kim TN, Feng QL, Kim JO, Wu J, Wang H, Chen GC, Cui FZ (1998). Antimicrobial effects of metal ions $\left(\mathrm{Ag}^{+}, \mathrm{Cu}^{2+}, \mathrm{Zn}^{2+}\right)$ in hydroxyapatite. J Mater Sci Mater Med 9(3) 129-134.

16. Kim YH, Woo KJ, Lim JH, Kim S, Lee TJ, Jung EM, Lee JM, Park JW, Kwon TK (2005). 8-Hydroxyquinoline inhibits iNOS expression and nitric oxide production by downregulating LPS-induced activity NF-kappaB and C/ EBPbeta in Raw 2647 cells. Biochem Biophys Res Commun 329(2): 591-597.

17. Maestrone G, Brandt W (1979). Evaluation of a cuprumyxin-hydrocortisone acetate suspension in the treatment of otitis externa in dogs and cats. Am J Vet Res 40(2): 285-287.

18. Mocanu A, Furtos G, Răpuntean S, Horovitz O, Flore C, Garbo C, Dăniștean A, Răpuntean Gh, Prejemrean C, Tomoaia-Cotisel M (2014). Synthesis: characterization and antimicrobial effects of composites based on multi-substituted hydroxyapatite and silver nanoparticles. Applied Surface Science, 298: 225-235.

19. Okide GB, Adikwu MU, Esimone CO (2000). Antimicrobial Activities of Some Amino Derivates of 5,7-Dibromo-2methyl-8-hydroxyquinoline. Biol Pharm Bull 23(2): 257258.

20. Prachayasittikul V, Prachayasittikul S, Ruchirawat S, Prachayasittikul Virapong (2013). 8-Hydroxyquinolines: a review of their metal chelating proprieties and medicinal applications. Drug Design Development and Therapy 7: 1157-1178.

21. Pavlov A, Takuchev N, Georgieva N (2012). Drug Design by Regression Analyses of Newly Synthesized Derivates of 8-quinolinol. Biotechnol Biotechnol Equip 26(1): 164169.

22. Rohde W, Mikelens P, Jackson J, Blackman J, Whitcher J, Levinson W (1976). Hydroxyquinolines inhibit ribonucleic acid-dependent deoxyribonucleic acid polymerase and inactivate Rous sarcoma virus and herpes simplex virus. Antimic Ag Chemother 10(2): 234-240.

23. Ruiz-Azuara L, Bravo-Gómez ME (2010). Cooper compounds in cancer chemotherapy. Curr Med Chem 17(31): 3606-3615.

24. Scăețeanu G, Pele M (2013). Cuprul: Un metal cu valențe multiple. NOEMA XII: 241-249.
25. Scheibel LW, Adler A (1982). Antimalarial activity of selected aromatic chelators III 8-hydroxyquinolines (oxines) substituted in posision 5 and 7 , and oxines annelated in position 5,6 by an aromatic ring. Mol Pharmacol 22(1): 140-144.

26. Shen AY, Chen CP, Roffler S (1999). A chelating agent possessing cytotoxicity and antimicrobial activity: 7-morpholinomethyl-8-hydroxyquinoline. Life Sci 64(9): 813-825.

27. Short BR, Vargas MA, Thomas JC, O'Hanlon S, Enright $\mathrm{MC}$ (2006). In vitro activity of a novel compound, the metal ion chelating agent $\mathrm{AQ}^{+}$against clinical isolates of Staphylococcus aureus. J Antimicrob Chemother 57(1): 104-109.

28. Srisung S, Suksrichavalit T, Prachayasittikul S, Ruchirawat S, Prachayasittikul V (2013). Antimicrobial activity of 8-hydroxyquinolone and transition metal complexes. Int J Pharmacol 9(2): 170-175.

29. Tomoaia Gh, Mocanu A, Vida-Simiti I, Jumate N, Bobos LD, Soritau O, Tomoaia-Cotisel M (2014). Silicon effect on the composition and structure of nanocalcium phosphates In vitro biocompatibility to human osteoblasts. Materials Science and Engineering C -Materials for Biological Applications 37: 37-47.

30. Tomoaia Gh, Soritau O, Tomoaia-Cotisel M, Pop LB, Pop A, Mocanu A, Horovitz O, Bobos LD (2013). Scaffolds made of nanostructured phosphates, collagen and chitosan for cell culture. Powder Technology 238: 99-107.

31. Tomoaia Gh, Tomoaia-Cotisel M, Pop LB, Mocanu A, Pop A (2013). Nanopowders of hydroxyapatite and its substituted derivates with medical applications and their fabrication procedure. Romanian Patent Number RO 125817 B1.

32. Vanparia SF, Patel TS, Sojitra NA, Jagani CL, Dixit BC, Patel PS, Dixit RB (2010). Synthesis, Characterization and Antimicrobial Study of Novel 4-\{[(8-hydroxyquinolin-5yl) methyl] amino benzensulfonamide and Its Oxinates. Acta Chim Slov 57(3): 660-667.

33. Vashi RT, Sheth NM (2013). Synthesis, characterization and antimicrobial activity of tetrazolium salt containing 8-hydroxy quinoline moiety in ligand and its chelates. Der Pharma Chemica 5(2): 230-236. 